\title{
Front Matter: Volume 10088
}

, "Front Matter: Volume 10088," Proc. SPIE 10088, Nonlinear Frequency Generation and Conversion: Materials and Devices XVI, 1008801 (5 May 2017); doi: 10.1117/12.2276090

SPIE. Event: SPIE LASE, 2017, San Francisco, California, United States 


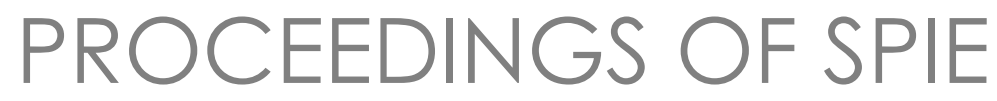

\section{Nonlinear Frequency Generation and Conversion: Materials and Devices XVI}

Konstantin L. Vodopyanov

Kenneth L. Schepler

Editors

30 January-1 February 2017

San Francisco, California, United States

Sponsored and Published by

SPIE 
The papers included in this volume were part of the technical conference cited on the cover and title page. Papers were selected and subject to review by the editors and conference program committee. Some conference presentations may not be available for publication. The papers published in these proceedings reflect the work and thoughts of the authors and are published herein as submitted. The publisher is not responsible for the validity of the information or for any outcomes resulting from reliance thereon.

Please use the following format to cite material from this book:

Author(s), "Title of Paper," in Nonlinear Frequency Generation and Conversion: Materials and Devices XVI, edited by Konstantin L. Vodopyanov, Kenneth L. Schepler, Proceedings of SPIE Vol. 10088 (SPIE, Bellingham, WA, 2017) Seven-digit Article CID Number.

ISSN: 0277-786X

ISSN: 1996-756X (electronic)

ISBN: 9781510606173

ISBN: 9781510606180 (electronic)

Published by

SPIE

P.O. Box 10, Bellingham, Washington 98227-0010 USA

Telephone +1 3606763290 (Pacific Time) · Fax +1 3606471445

SPIE.org

Copyright (C) 2017, Society of Photo-Optical Instrumentation Engineers.

Copying of material in this book for internal or personal use, or for the internal or personal use of specific clients, beyond the fair use provisions granted by the U.S. Copyright Law is authorized by SPIE subject to payment of copying fees. The Transactional Reporting Service base fee for this volume is $\$ 18.00$ per article (or portion thereof), which should be paid directly to the Copyright Clearance Center (CCC), 222 Rosewood Drive, Danvers, MA 01923. Payment may also be made electronically through CCC Online at copyright.com. Other copying for republication, resale, advertising or promotion, or any form of systematic or multiple reproduction of any material in this book is prohibited except with permission in writing from the publisher. The CCC fee code is $0277-786 \mathrm{X} / 17 / \$ 18.00$.

Printed in the United States of America.

Publication of record for individual papers is online in the SPIE Digital Library.

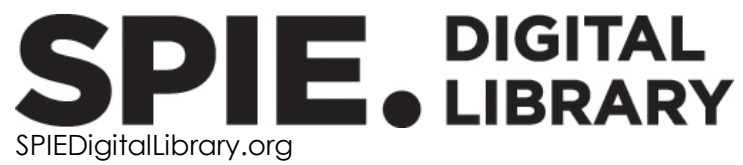

Paper Numbering: Proceedings of SPIE follow an e-First publication model, with papers published first online and then in print. Papers are published as they are submitted and meet publication criteria. A unique citation identifier (CID) number is assigned to each article at the time of the first publication. Utilization of CIDs allows articles to be fully citable as soon as they are published online, and connects the same identifier to all online, print, and electronic versions of the publication. SPIE uses a seven-digit CID article numbering system in which:

- The first five digits correspond to the SPIE volume number.

- The last two digits indicate publication order within the volume using a Base 36 numbering

system employing both numerals and letters. These two-number sets start with $00,01,02,03$,

$04,05,06,07,08,09,0 A, 0 B \ldots$. OZ, followed by 10-1Z, 20-2Z, etc.

The CID Number appears on each page of the manuscript. The complete citation is used on the first page, and an abbreviated version on subsequent pages. 


\title{
Contents
}

\author{
vii Authors \\ ix Conference Committee
}

\section{VISIBLE-UV GENERATION}

$1008802 \quad 1.9 \mathrm{~W}$ yellow, CW, high-brightness light from a high efficiency semiconductor laser-based system [10088-1]

$1008803 \quad 3.5 \mathrm{~W}$ of diffraction-limited green light at $515 \mathrm{~nm}$ from SHG of a single-frequency tapered diode laser [10088-2]

$1008804 \quad 149.8 \mathrm{~nm}$, the shortest wavelength generated by phase matching in nonlinear crystals [10088-3]

1008805 Compact, integrable, and long life time Raman multiline UV-Vis source based on hypocycloid core Kagome HC-PCF [10088-4]

1008808 Picosecond pulsed micro-module emitting near $560 \mathrm{~nm}$ using a frequency doubled gainswitched DBR ridge waveguide semiconductor laser [10088-7]

FREQUENCY COMBS WITH OPTICAL RESONATORS II: JOINT SESSION WITH CONFERENCES 10088 AND 10090

1008809 Instantaneous spectral span of $2.85-8.40 \mu \mathrm{m}$ achieved in a Cr:ZnS laser pumped subharmonic OPO (Invited Paper) [10088-8]

\section{SUPERCONTINUUM AND RAMAN GENERATION}

$10088 \mathrm{OB}$ Experimental investigation of mid-infrared supercontinuum generation in chalcogenide step-index optical fibers (Invited Paper) [10088-10]

10088 OC Supercontinuum comb sources for broadband communications based on AIGaAs-oninsulator (Invited Paper) [10088-11]

$10088 \mathrm{OE} \quad$ All-fiber supercontinuum source with flat, high power spectral density in the range between $1.1 \mu \mathrm{m}$ to $1.4 \mu \mathrm{m}$ based on an Yb3+ doped nonlinear photonic crystal fiber [10088-13]

10088 OG Exploring nonlinear pulse propagation, Raman frequency conversion and near octave spanning supercontinuum generation in atmospheric air-filled hollow-core Kagomé fiber [10088-15]

$10088 \mathrm{OH} \quad$ High power Raman-converter based on $\mathrm{H}_{2}$-filled inhibited coupling HC-PCF [10088-16] 
NONLINEAR OPTICAL DEVICES AND TECHNIQUES I

10088 Ol Upconversion based spectral imaging in 6 to $8 \mu \mathrm{m}$ spectral regime [10088-17]

$10088 \mathrm{OJ} \quad$ Broadband upconversion imaging around $4 \mu \mathrm{m}$ using an all-fiber supercontinuum source [10088-18]

$10088 \mathrm{OL} \quad$ Investigation of mid-IR picosecond image upconversion [10088-20]

10088 ON Cross-propagating beam-deflection measurements of third-order nonlinear optical susceptibility [10088-21]

NONLINEAR OPTICAL DEVICES AND TECHNIQUES II

$100880 Q \quad$ Quantum superradiant amplification in rubidium vapors: gain assessment [10088-24]

NEW NONLINEAR MATERIALS

10088 OU Development of orientation-patterned GaP grown on foreign substrates for QPM frequency conversion devices [10088-28]

10088 OV Broadband midinfrared from fiber laser difference frequency generation in OP-GaP [10088-29]

10088 OW Continuous-wave difference frequency generation in the mid-infrared with orientationpatterned gallium phosphide (OP-GaP) crystals [10088-30]

OPTICAL PARAMETRIC DEVICES AND APPLICATIONS I

10088 OY Molecular spectroscopy from 5-12 um using an OP-GaP OPO (Invited Paper) [10088-32]

$10088 \mathrm{OZ}$ Single-frequency tunable long-wave infrared OP-GaAs OPO for gas sensing (Invited Paper) [10088-33]

$1008810 \quad$ Frequency down-conversion of $1 \mu \mathrm{m}$ laser radiation to the mid-IR using non-oxide nonlinear crystals in a cascaded intracavity configuration (Invited Paper) [10088-34]

\section{OPTICAL PARAMETRIC DEVICES AND APPLICATIONS II}

1008812 Large-scale artificial spin network based on time-multiplexed degenerate optical parametric oscillators for coherent Ising machine (Invited Paper) [10088-36]

1008813 Nonlinear frequency conversion of structured beams and Airy beam optical parametric oscillator (Invited Paper) [10088-37]

1008814 Dispersion tuning of a narrow-linewidth picosecond OPO based on chirped quasi-phase matching with a volume Bragg grating [10088-38] 
1008815 Combined visible and near-infrared OPA for wavelength scaling experiments in strongfield physics [10088-39]

POSTER SESSION

1008817 Nonlinear mode conversion for intermodal four-wave mixing Stokes and anti-Stokes in a multimode fiber [10088-41]

10088 1A Modulation of frequency doubled DFB-tapered diode lasers for medical treatment [10088-44] 
Proc. of SPIE Vol. 10088 1008801-6

Downloaded From: https://www.spiedigitallibrary.org/conference-proceedings-of-spie on 26 Apr 2023 Terms of Use: https://www.spiedigitallibrary.org/terms-of-use 


\section{Authors}

Numbers in the index correspond to the last two digits of the seven-digit citation identifier (CID) article numbering system used in Proceedings of SPIE. The first five digits reflect the volume number. Base 36 numbering is employed for the last two digits and indicates the order of articles within the volume. Numbers start with 00, 01, 02, 03, 04, 05, 06, 07, 08, 09, OA, OB...0Z, followed by 10-12, 20-2Z, etc.

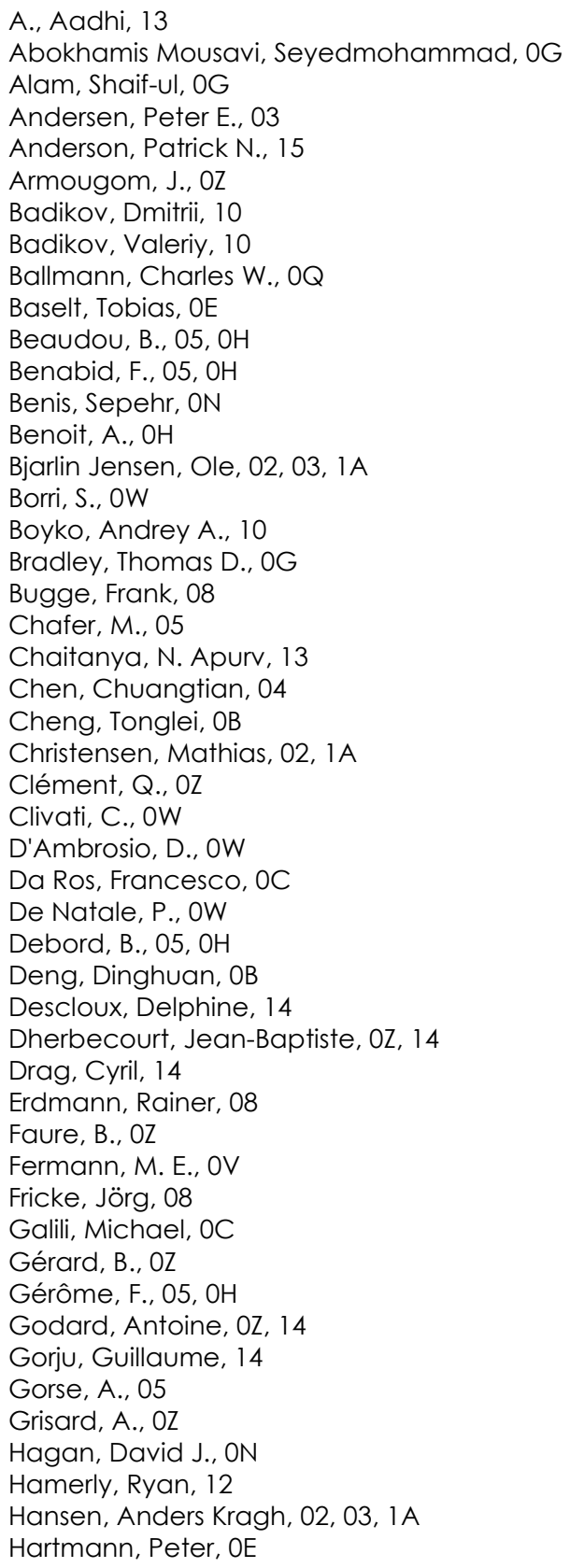


Paschke, Katrin, 08

Pasiskevicius, Valdas, 10

Pedersen, Christian, Ol, OJ, OL

Petersen, Paul Michael, 03

Peterson, Rita, OU

Petrov, Valentin, 10

Poletti, Francesco, 0G

Pourbeyram, Hamed, 17

Pu, Minhao, OC

Raybaut, Myriam, 0Z, 14

Reid, Derryck T., OY

Richardson, David, OG

Rodrigo, Peter John, OL

Ru, Qitian, 09

Samanta, G. K., 13

Sandoghchi, Seyed Reza, OG

Santambrogio, G., OW

Schunemann, Peter G., 09, 0V, OW, OY

Seidel, Dirk, 08

Shevyrdyaeva, Galina, 10

Skovgaard, Peter M. W., 02, 1 A

Snure, Michael, OU

Souhaité, $\mathrm{G} ., \mathrm{OZ}$

Stock, M. L., 02

Sumpf, Bernd, 03

Suzuki, Takenobu, OB

Takesue, Hiroki, 12

Tassev, Vladimir, OU

Taudt, Christopher, OE

Tezuka, Hiroshige, OB

Tidemand-Lichtenberg, Peter, Ol, OJ, OL

Tränkle, Günther, 08

Traverso, Andrew J., OQ

Treacher, Daniel, 15

Tuan, Tong Hoang, OB

Van Stryland, Eric W., ON

Vangala, Shivashankar, OU

Vasilyev, Sergey, 09

Vodopyanov, Konstantin L., 09

Walter, Guillaume, 14

Wang, Xiaoyang, 04

Watanabe, Shuntaro, 04

Wheeler, Natalie, $0 \mathrm{G}$

Wyatt, Adam S., 15

Yakovlev, Vladislav V., $0 Q$

Yamamoto, Yoshihisa, 12

Yuan, Luqi, $O Q$

Yvind, Kresten, OC

Zhong, Kai, 09

Zondy, J.-J., OW

Zukauskas, Andrius, 10 


\section{Conference Committee}

Symposium Chairs

Reinhart Poprawe, Fraunhofer-Institut für Lasertechnik (Germany)

Koji Sugioka, RIKEN (Japan)

Symposium Co-chairs

Guido Hennig, Daetwyler Graphics AG (Switzerland)

Yongfeng Lu, University of Nebraska-Lincoln (United States)

Program Track Chairs

Vladimir Ilchenko, OEwaves, Inc. (United States)

Paul O. Leisher, Rose-Hulman Institute of Technology (United States)

Conference Chairs

Konstantin L. Vodopyanov, CREOL, The College of Optics and Photonics, University of Central Florida (United States)

Kenneth L. Schepler, CREOL, The College of Optics and Photonics, University of Central Florida (United States)

Conference Program Committee

Darrell J. Armstrong, Sandia National Laboratories (United States)

Majid Ebrahim-Zadeh, ICFO - Institut de Ciències Fotòniques (Spain)

Baldemar Ibarra-Escamilla, Instituto Nacional de Astrofísica, Óptica y

Electrónica (Mexico)

Rita D. Peterson, Air Force Research Laboratory (United States)

Peter G. Schunemann, BAE Systems (United States)

Wei Shi, Tianjin University (China)

Michael Vasilyev, The University of Texas at Arlington (United States)

\section{Session Chairs}

1 Visible-UV Generation

Darrell J. Armstrong, Sandia National Laboratories (United States)

2 Frequency Combs with Optical Resonators I: Joint Session with Conferences 10088 and 10090

Konstantin L. Vodopyanov, CREOL, The College of Optics and Photonics, University of Central Florida (United States) 
3 Frequency Combs with Optical Resonators II: Joint Session with Conferences 10088 and 10090

Andrea M. Armani, The University of Southern California

(United States)

4 Supercontinuum and Raman Generation

Konstantin L. Vodopyanov, CREOL, The College of Optics and Photonics, University of Central Florida (United States)

5 Nonlinear Optical Devices and Techniques I

Peter G. Schunemann, BAE Systems (United States)

6 Nonlinear Optical Devices and Techniques II

Rita D. Peterson, Air Force Research Laboratory (United States)

7 New Nonlinear Materials

Rita D. Peterson, Air Force Research Laboratory (United States)

8 Optical Parametric Devices and Applications I

Darrell J. Armstrong, Sandia National Laboratories (United States)

9 Optical Parametric Devices and Applications II

Wei Shi, Tianjin University (China) 